\title{
Detection of Norovirus and Rotavirus in Children under Five Years During Winter 2012-2013 in Mosul Province
}

\author{
Nadira Salman Mohamed*1, Mohammed Fadhel Hameed ${ }^{* * 2}$ and Haider Khadum Al-Rubai**3 \\ ${ }^{* * * * *}$ Forensic DNA Research and Training Center. \\ **Technical Institute, Mosul, Foundation of Technical Education. \\ ${ }^{1}$ E-mail: nadmohamed2000@yahoo.com. \\ ${ }^{2}$ E-mail: mf_mf_mf8@yahoo.com. \\ ${ }^{3}$ E-mail: hayderkhadum@yahoo.com.
}

\begin{abstract}
The identifying the viral agents such as norovirus genogroup I (NVGI), norovirus genogroup II (NVGII) and rotavirus (RV) is critical to the development of effective preventive measures. This study aimed to determine the prevalence of common enteric viruses in children $<5$ years old presented with diarrhea in Mosul Governorate. Due to the lack of recent reports on surveillance of rotavirus and norovirus infection in, One hundred fecal samples were collected between December 2012 to March 2013 from children <5 years of age who presented with acute gastroenteritis in the Al-Salam hospital and Al-Madena clinical laboratory in Mosul. All samples were tested for rotavirus using latex agglutination test, and norovirus using (RT-qPCR) for NVGI and NVGII. Enteric viruses were detected in 42 out of the 100 (42\%) children who presented with acute diarrhea. In that 42 samples positive for enteric viruses, at least one viral agent was found. NVGII was the most frequent virus identified in 24 cases $(57.14 \%$ ), followed by rotavirus in 14 cases (33.33\%), and NVGI in 4 cases $(9.52 \%)$. The result demonstrated a high prevalence infection with the both viruses in age group under 1years with high incidence of 22 Bottle-Feed 22 cases $(52.37 \%)$.Norovirus and Rotavirus co-infection was occurred in 9 cases presented $21.24 \%$ of all cases.
\end{abstract}

Keywords: Norovirus, Rotavirus, RT-qPCR, Acute gastroenteritis, Bottle-Fed.

\section{Introduction}

Rotavirus (RV) and Norovirus (NoV) are major causes of pediatric diarrhea and are altogether associated with approximately 800,000 deaths in young children every year (1). Noroviruses (NoVs) cause acute debilitating illness in people of all ages, the illness typically begins after an incubation period of 22-48 hours characterized by vomiting, diarrhea, fever, nausea, vomiting, cramping, malaise, and diarrhea persisting for 2 to 5 days (2). Norovirus, belonging to the family of Caliciviridae. NoVs are nonenveloped viruses with a single-stranded, positive-sense, polyadenylated RNA genome of about 7500 nucleotides (nt) in length. Three overlapping ORFs encode the nonstructural (ORF1) and structural (ORF2 and ORF3) viral Proteins (3). NoVs in nature is genetically and antigentically highly diverse (4). NoV is tentatively divided into five genogroups (GI to GV) Most NoVs infecting humans belong to genogroups GI and GII. GI genogroup is further subdivided into at least eight genotypes and GII genogroup into 17 genotypes. The virus is highly transmissible requiring a very low infectious dose of $<10-100$ virions. The key factors underpinning this high burden of infection are their low infectious dose, and their stability in the environment (acids, $\mathrm{pH}$, chloride and temperature), the wide diversity of strains and the lack of any long-term immunity to an infection or illness $(4,5,6,7)$. Volunteer studies indicate that immunity to NoVs seems to be short lived and that immunity to one strain does not provide good protection from infection with other heterogeneous strains (8). The viruses are very contagious and infect persons of all ages who consume contaminated food or water or who have close contact with infected persons (7). Infection can be especially virulent in young children, the elderly, and the immunocompromised (2). The US Centers for Disease Control and Prevention estimates that it is the most common cause of acute 
gastroenteritis in the United States with 21 million cases each year and an estimated 70,000 hospitalizations and 8000 deaths (5). The availability of RV vaccines has made NoVs the most common cause of medically attended acute gastroenteritis in American children younger than 5 years (9). Approximately half of the NoV-related visits involved children aged 6-18 months $(9,10)$.

\section{Materials and Methods}

The study involved the collection of 100 stool samples were collected from children under 5 years with clinical symptoms of nonbacterial non- parasitic Acute Gastroenteritis (AGE): nausea, vomiting and/or three or more loose stools in $24 \mathrm{hrs}$. during the acute phase of the infection in sterile plastic water proof containers. Samples were transported to the laboratory on ice in sealed bag stored at $+4^{\circ} \mathrm{C}$ in refrigerator until processing. After examination, samples were stored at $-20^{\circ} \mathrm{C}$ (11). RNA extraction from viral RNA: $30 \%$ $(\mathrm{w} / \mathrm{v})$ stool suspensions were made in phosphate-buffered saline (PBS;7.2pH). Extractions were performed using the QIAamp1Viral RNA Mini kit (Qiagen, Germany) according to the manufacturer's instructions. Real-time quantitative reverse transcription-PCR (RT-qPCR)(Lazaro, 2010). Viral RNA was extracted from $140 \mu \mathrm{L}$ of supernatant with a QIAamp viral RNA mini kit (Qiagen, Germany). RT-qPCR was performed using Go Tag 1 step RT -qPCR reaction kit from (Promega). Three sets of specific primers, QNIF4 (5--CGC TGG ATG CGN TTC CAT $\left.-3^{-}\right)$, NV1LCR $\left(5^{-}\right.$- CCT TAG ACG CCA TCA TCA TTT AC- $3^{-}$), and NVGG1P probe (5--FAM- TGG ACA GGA GAY CGC RAT CT-BHQ1-3-) were used to detect NV GI and QNIF2 (5-- ATG TTC AGR TGG ATG AGR TTC TCW GA -3 ${ }^{-}$), COG2R (5- $5^{-}$TCG ACG CCA TCT TCA TTC ACA $\left.3^{-}\right)$. QNIFS (5- FAM- AGC ACG TGG GAG GGC GAT CG -BHQ1-3 ${ }^{-}$). probe were used to detect NVGII, respectively with using IACP (5-VIC- CCA TAC ACA TAGGTC AGG MGB- NFQ- $3^{-}$) (Applied biosystem UK). RTqPCR was performed with an ABI Prism 7500 sequence detector (Applied Biosystem) under the following conditions: (1) Revers transcription $\geq 37^{\circ} \mathrm{C}$ for $15 \mathrm{~min}$, (2) Hot start activation $95^{\circ} \mathrm{C}$ for $10 \mathrm{~min}$, (3) steps q PCR 40 cycles of amplification with denaturation at 95 for $10 \mathrm{sec}$, annealing at $60^{\circ} \mathrm{C}$ for $30 \mathrm{sec}$ and extension at $72^{\circ} \mathrm{C}$ for $30 \mathrm{sec}$. ROTA-VIRUS LATEX TEST KIT It is a rapid latex agglutination assay for the detection of Rotavirus in fecal samples. Stool suspensions were prepare a $10 \%$ suspension of the fecal sample by adding $0.1 \mathrm{ml} / 0.1 \mathrm{~g}$ of sample to $1 \mathrm{ml}$ of extraction buffer in a screw capped vial. Mix well. Stand at room temperature for 2 minutes, then examined according to the manufacturer's instructions. A positive result is indicated by the visible agglutination of the test latex particles. This will normally occur within a few seconds of mixing, depending on the strength of the extract. A negative result is indicated by a milky appearance without any visible aggregation of the latex particles. (plasmatic lab product, 2010).

\section{Statistical Analysis}

Descriptive statistics are shown as percentages and ratios. Chi square $(\chi 2)$ test was used to compare groups. Probability $\mathrm{P} \leq 0.01$ was regarded as statistically significant. Multivariate analysis was performed using a logistic regression method. In this test positive virus was used as the dependent variable and other clinical findings were used as independent variables. The test was used for each virus separately (SAS, 2010).

\section{Results}

Stool samples were collected from 100 patients with AGE from Mosul province, $42 / 100(42 \%)$ were found positive to one of these viruses: NVGI 4/42(9.52\%), NVGII 24/42(57.14\%), and RV 14/42(33.33\%) infection showed Fig.(1). 


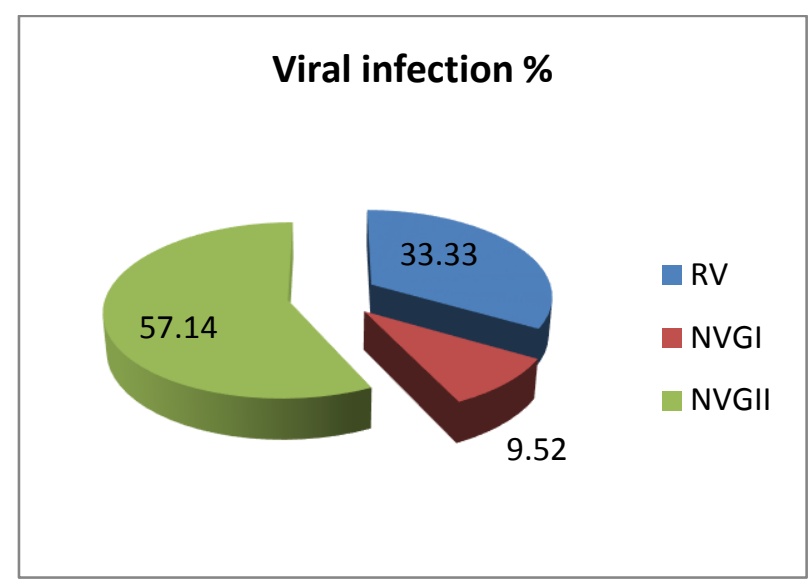

Fig.(1): The percentage of NVGI, NVGII, and $R V$ infections among children under five years old in Mosul governorate ( $R$ V=Rotavirus, $N$ VGI=Norovirus Genogroup 1, NVGII=Norovirus Genogroup 2).

The result in Fig.(2) shows that the highest incidence of NVGII infection 17/42 (40.47\%) appeared among age group under one year's followed by RV infection 11/42 (26.19\%), and NVGI infection 3/42 (7.14\%) of the same age group. Infections recede gradually in the second age group and the NVGII 4/42 (9.52\%) stays superior to the other in this age group viruses. Norovirus and rotavirus co- infection was seen in nine cases represented $21.42 \%$ of positive cases followed by NVGI-NVGII Coinfection which appeared in 2 cases $(4.76 \%)$ and only one case was found positive for the three viruses in compared with mono-infection which appeared in 12 cases of NVGII
(28.57\%), and in three cases of rotavirus while was not found any mono-infection with NVGI as shown in Fig.(3).

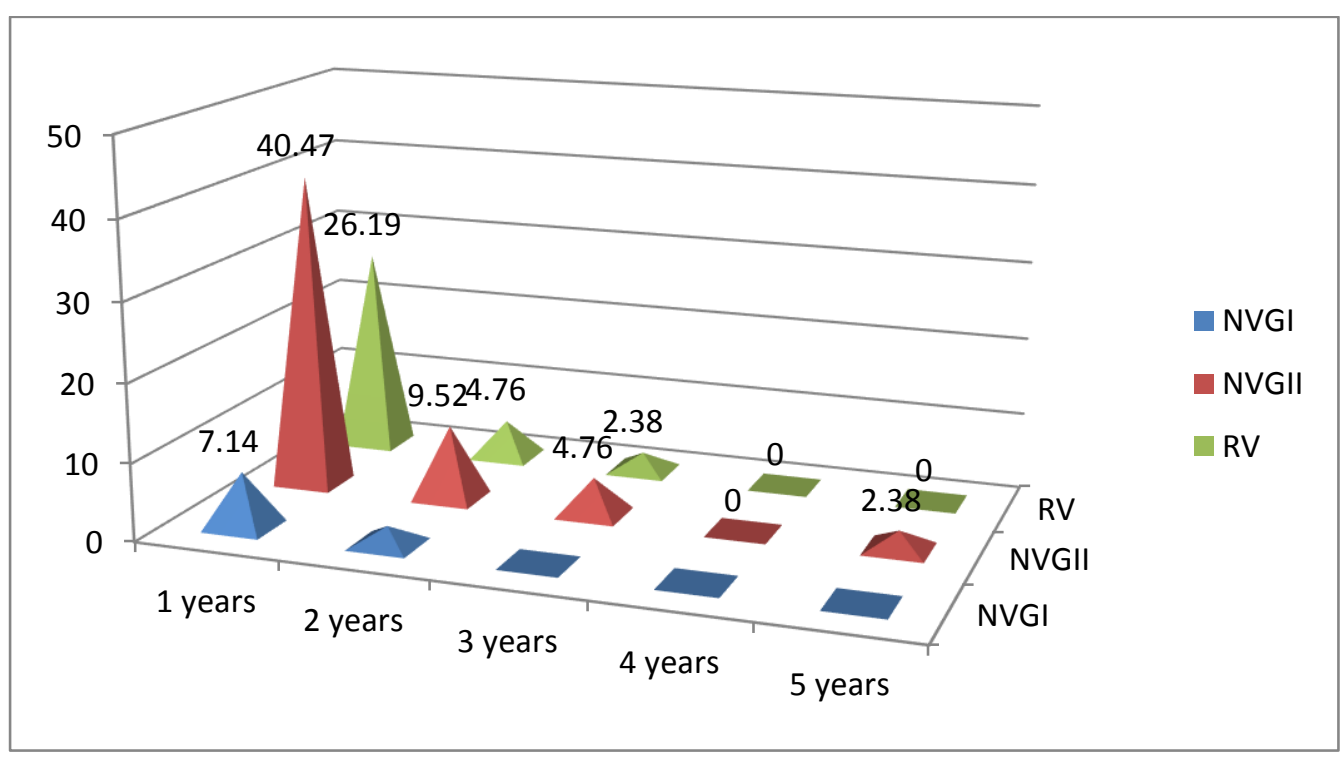

Fig.(2): The percentage of viral infection distribution among five age group of patients. 


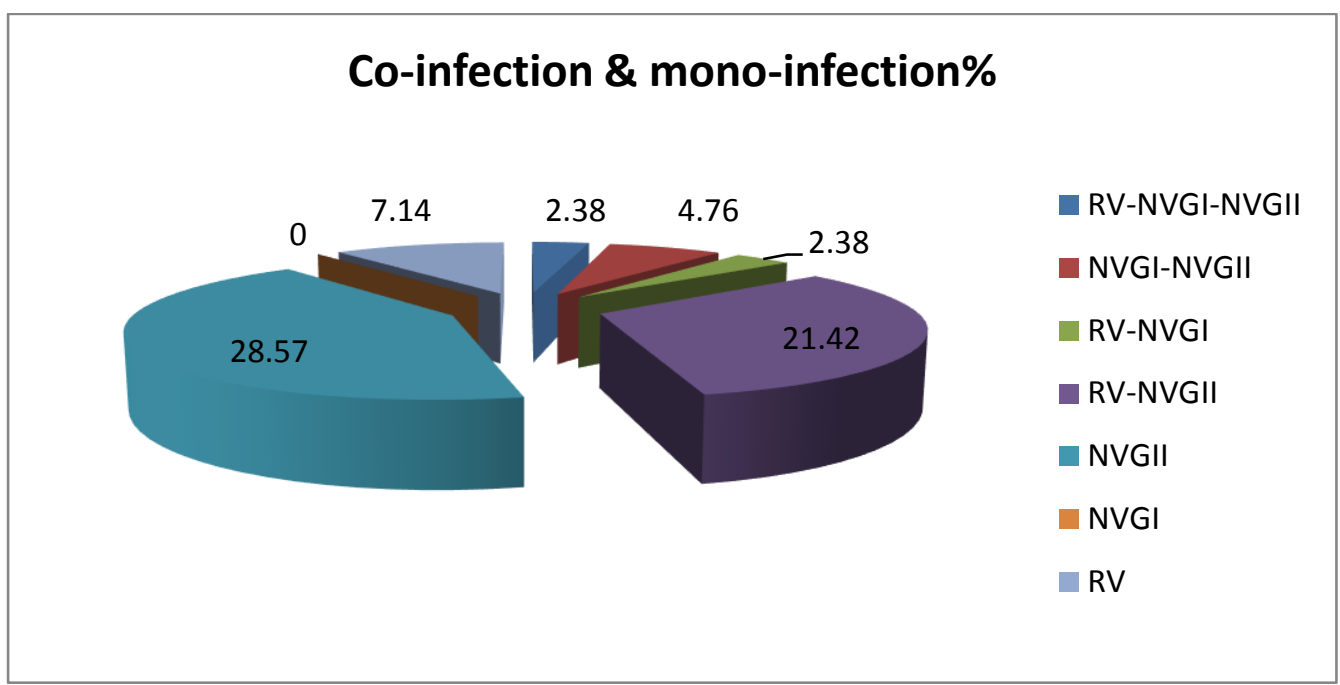

Fig.(3): The percentage of $R V$, NVGI, and NVGII Mono-infection and co-Infection.

Fig.(4) shows the relationship between pediatric feeding type and the percentage of infection indicate an elevated incidence of the NVGII $26.19 \%$, RV $19.04 \%$, and NVGI $7.4 \%$ respectively in the group bottle-fed by on the other hand, significant association $(\mathrm{p} \leq 0.001)$ was found between bottle-fed and viral gastroenteritis.

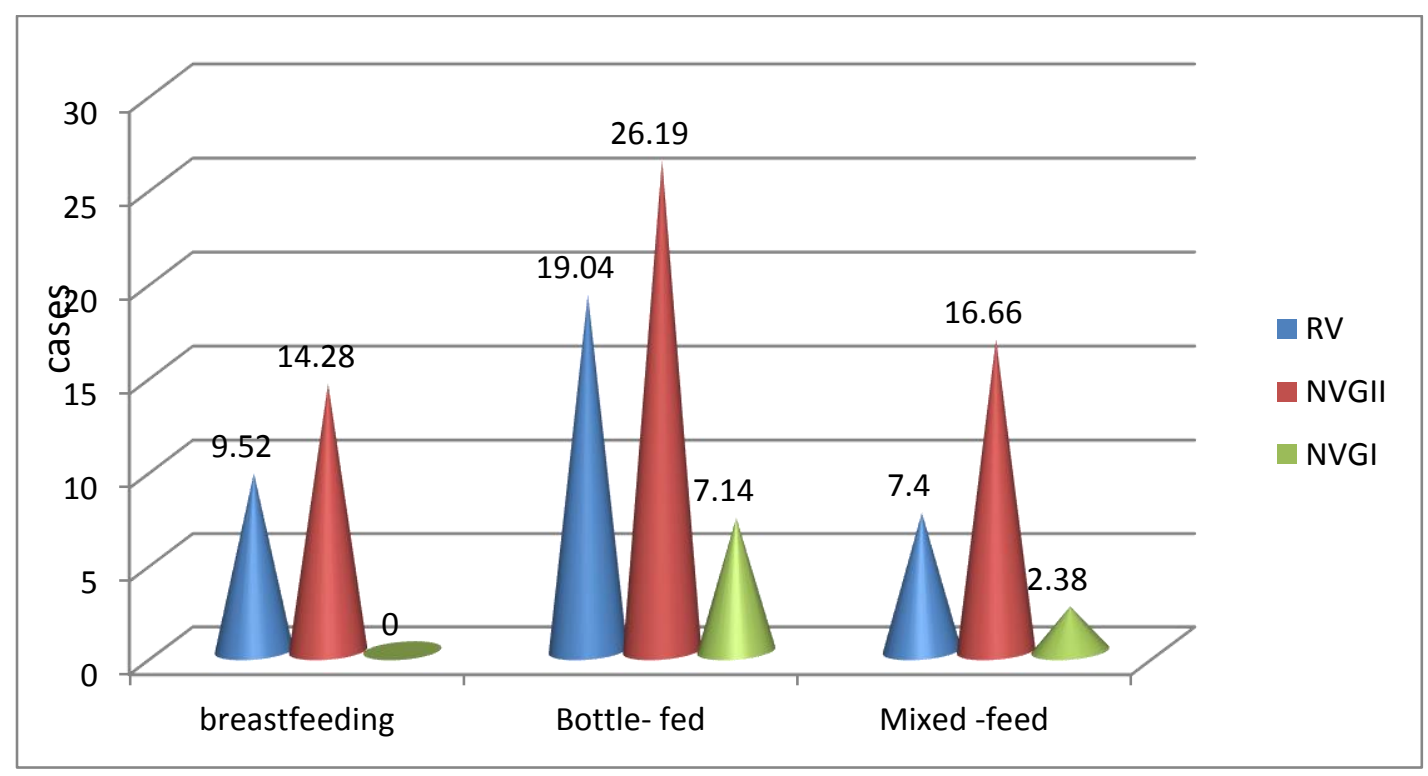

Fig.(4): The percentage AGE cases as influenced by the feeding methods among pediatric patients under two years old.

\section{Discussion}

This study investigated100 stool samples collected from children under five years from Mosul governorate, 42 samples from nonbacterial non-parasitic stool were found positive to one of these viruses NVGI, NVGII, and RV infection. This information was extracted from patient using diarrhea case report form as shown in Figure1. aslo, all samples were examined using RT-PCR. The genomic region was utilized to detect and genotype NoV by RT-qPCR codify to the RNA Depending RNA polymerase gene ( $R d R p)$, which is relatively conserved in both genogroups of NVGI and NVGII. The results showed an increase in NVGII infection and 
superiority over RV and NVGI infection. These results were similar to the ones that have been mentioned by Chan and Chan [14], and with early study in Baghdad the Capital of Iraq by Mohamed et al [15]. Involving the correlation between age under two years and the incidence of NVGII infection indicated that there was a statistically highly significant $(\mathrm{p}<0.01)$ correlation. In this survey, 14 (33.3\%) positive rotavirus cases were detected out of 100 children. The significant differences between rotavirus incidence and different age groups are agree with other reports from United Kingdom, Indonesia and Nigeria respectively $[16,17,18]$. The rate of rotavirus positivity in children aged less than 2 years was $30.95 \%$. This finding is higher than those reported in Turkey (21\%) [19], but it is lower than those reported in northern Iran (62\%) [20]. The lower percentage of RV virus in older ages, is probably due to their past infection in early childhood which might earn immunity against infection in the future and also using RV vaccine. The past infection with NoVs did not earn immunity against reinfection with the same genotype.

In general co-infections are less frequent than mono-infections. RV and NVGII co- infection were found in 9 cases presented $21.24 \%$ of all samples. NVGI, and NVGII co-infection were found in 2 cases presented $4.7 \%$ of all collected samples in compared with NVGII mono-infection which appeared in 12 cases represents $28.57 \%$ of all cases. These results were expected by [22] in Mexican children and with [21] which refers to the age group (7-18 months) was the most affected with Human Calicivirus (HuCV) infection ,corresponded to that group was most commonly affected by RV, with a median age of 12 months. Mixed infections were predominantly detected in children under 1year age group and this is consistent with observations seen by [23] who explains that virus-virus co-infections were significantly more frequent in 7-18 months age group. Norovirus excretion can continue for long periods for up to 44.5 days following onset of symptoms in a naturally infected individual [24] in India, this may explain the causes behind the mixed infection with rotavirus in asymptomatic patients. However, the fact that
$\mathrm{NoV}$ is the leading cause of clinical diarrhea in the United States also suggests that NoV could likely be a cause of severe disease among children in lesser-developed countries. Future epidemiological studies should consider quantitative diagnostics in the design to more precisely attribute pathogen etiology. Based on available epidemiological data it appears that NoV has a similar epidemiology to $\mathrm{RV}$ in incidence among children less than five years of age, with the highest incidence rates and multiple infections occurring in the first two years of life.

A previous birth cohort study in Peru illustrates this epidemiology changing dynamics in strain variation and circulation could likely also explain the high incidence beyond two years of life (25). Immunity to $\mathrm{NoV}$ is usually incomplete and temporary [26]. The protective immunity to the same strain of NoV lasts for six months, but that all such immunity is gone after two years [27]. Thus, a successful vaccination strategy will be needed to target children at the earliest age in order to have maximum effect.

Infants who are breastfed are at an immunological advantage when compared with formula feed infants these advantages indicate a biological link between a mother and her infant via the factors supplied in the milk. While the transfer of a number of factors in human milk including immunoglobulins, lactoferrin and oligosaccharides provide passive protection for the recipient infant, it may be speculated that alterations to the propensity for chronic wheezing illness are more likely due to factors capable of modulating the development of the infant immune system [28].

During the study of the relationship between the incidence of virus subject of the study and the pattern of nutrition in infant showed in Fig.(4). We obtained the highly incidence with both viruses NVGII (26.19\%) and $\mathrm{RV}(19.04 \%)$ in infant using bottle-feed in comparing with infants who are breast-fed and mix-feed. This is due to the ease of transmission of viruses in contaminated feeding bottles. The association between bottle-fed and viral infection statically was highly significant $(p \leq 0.01)$. According to the relatively high prevalence of viral 
gastroenteritis observed in this study and previous study covered Baghdad city also with the limited published data in this field in different Iraq provinces. It is imperative to develop a strategy for further surveys for the distribution of gastroenteritis viruses in different Iraqi provinces and to develop effective plans for immunization.

\section{Conclusions}

NVGII is the most predominant enteric virus in children $<5$ years old in Mosul province followed by rotavirus in age group under 1 years with high incidence in Bottlefed.

\section{References}

[1] Bucardo F. and Nordgren J., "Rotavirus overview"; J. Pediatric. Infect. Dis, 28 (3): 50-53, 2011.

[2] Patel M M., Widdowson M A., Glass G I., Akazawa K., Vinjé J., and Parashar UD., "Systematic literature review of role of noroviruses in sporadic gastroenteritis", Emerg. Infect. Dis, 14, 1224-1231. 2008.

[3] Green, K.Y., Ando T, Balayan MS, Berke $\mathrm{T}$, Clarke IN, Estes MK, Matson DO, Nakata S, Neill JD, Studdert MJ, Thiel HJ., "Taxonomy of the caliciviruses. J Infect", 181:S322-330, 2000.

[4] Kageyama T M, Shinohara K, Uchida S, Fukushi F B, Hoshino S, Kojima R, Takai $\mathrm{T}$, Oka N T, and Katayama K., "Coexistence of multiple genotypes, including newly identified genotypes, in outbreaks of gastroenteritis due to Norovirus in Japan". J. Clin. Microbiol., 42:2988-2995. 2004.

[5] Hall A J, Lopman B A, Payne D C, Patel M M, Gastañaduy P A, Vinjé J, and Parasha U D., "Norovirus Disease in the United States", J .Emerging. infect. Dis, 19(8):1198-1205. 2013.

[6] Fankhauser R L, Monroe S S, Noel J S, Humphrey C D, Bresee J S, Parashar U D, Ando T, Glass R I., "Epidemiologic and molecular trends of Norwalk-like viruses associated with outbreaks of gastroenteritis in the United States", J. Infect. Dis, 186:17. 2002.

[7] Rockx B, Wit M, Vennema H, Vinje 'J, Bruin E d, Duynhoven Y, Koopmans M.,
"Natural history of Human Calicivirus infection: a prospective cohort study", Clin. Infect. Dis, 35: 246- 253, 2002.

[8] Matsui, S.M., Greenberg, H.B., "Immunity to Calicivirus infection”. J. Infect. Dis. 181 (2): 331-335, 2000.

[9] CDC., "Emergence of new Norovirus strain GII.4 Sydney -United States", 2012. MMWR., 62(3):55,2013.

[10] Payne D C, Jan Vinjé H, Szilagyi P G, Edwards K M, Staat M A, Weinberg Hall C B, Bernstein D I, Curns A T, Wikswo M, Lopman B, and S H, Hall A J. Parashar U D., "Norovirus and Medically Attended Gastroenteritis in U.S. Children", Engl J .Med, 368:1121-1130, 2013.

[11] Lazaro D R. "Detection and quantification of Norovirus by real time PCR”. SOP Vital, 018, 2010.

[12] Plasmatec Laboratory Product. RotaVirus Latex Test Kit. Dreadnought trading Estate, Bridport, Dorset UK DT6 5BU, 2010.

[13] SAS., "Statistical Analysis System, User's Guide". Statistical. Version 9.1th ed. SAS. Inst. Inc. Cary. N.C. USA, 2012.

[14] Chan M C, Chan P K., "Complete genome sequence of a novel recombinant human norovirus genogroup II genotype 4 strain associated with an epidemic during summer of 2012 in Hong Kong", Genome. Announc. 1(1):140-142, 2013.

[15] Mohamed N S, Habeb K A, Faisal G. Nasser, Ahmed M A, Ali LK and Najim A T., "The incidence of Norovirus compared with Rotavirus in Baghdad City". International. Journal .of Advanced. Research, 1(10): 855-863, 2013.

[16] Subekti D, Lesmana M, Tjaniadi P, Safari N, Frazier E, Simanjuntak C,. "Incidence of Norwalk-like viruses, rotavirus and adenovirus infection in patients with acute gastroenteritis in Jakarta, Indonesia", FEMS Immunol. Med. Microbiol, 33(1):2733, 2002.

[17] Odimayo M S, Olanrewaju W I, Omilabu S A, Adegboro B., "Prevalence of rotavirus-induced diarrhea among children under 5 years in Ilorin, Nigeria". J Trop Pediatr, 54(5):343-6, 2008.

[18] Cortese M M, Parashar U D., "Prevention of Rotavirus Gastroenteritis among Infants 
and Children. Recommendations of the Advisory Committee on Immunization Practices (ACIP)". MMWR Recommend, 58 (RR02):1-25, 2006.

[19] Akan H, Izbirak G, Gurol Y, Sarikaya S, Gunduz TS, Yilmaz G., "Rotavirus and adenovirus frequency among patients with acute gastroenteritis and their relationship to clinical parameters: a retrospective study in Turkey", Asia Pac Fam Med, 8(1):8, 2009.

[20] Hamkar R, Yahyapour Y, Noroozi M, Nourijelyani K, Jalilvand S, Adibi L, Vaziri S, Poor-Babaei A A, Pakfetrat A, and Savad-Koohi R., "Prevalence of Rotavirus, Adenovirus, and Astrovirus Infections among Patients with Acute Gastroenteritis in, Northern Iran", Iran J Public Health, 39(2):45-51, 2010.

[21] Mandell G L, Bennett J E, and Dolin R., "Mandell's Principles and Practices of Infection Diseases". $6^{\text {th }}$ ed. Churchill Livingstone, 392-398.2004.

[22] Gómez-Santiago F, Ribas -Aparicio R M, and livingstone $\mathrm{H}$ G., "Molecular characterization of human Calicivirus associated with acute diarrheal disease in Mexican children". J.Virol, 9:954. 2010.

[23] Buckow R, Isbarn S, Knorr D, Heinz V, and Anselm L., "Predictive Model for Inactivation of Feline Calicivirus, a Norovirus Surrogate, by Heat and High Hydrostatic Pressure", Appl. Environ. Microbial, 74(4):1030-1038. 2008.

[24] Menon V K, George S, Ramani S, liayaraja J, Sarkar R, Jana A K, Kuruvilla A K, and Kang G., "Genogroup IIb Norovirus Infections and Association with Enteric Symptoms in a Neonatal Nursery in Southern India". J. Clin. Microbiol, 48(9): 3212-3215, 2010.

[25] Saito M, Goel-Apaza S, Espetia S et al. "Multiple Norovirus Infections in a Birth Cohort in a Peruvian Periurban Community". Clin. Infec. Dis, 2014: 58(4): 483-491.

[26] Lindesmith L, Moe C, Lependu J, Frelinger JA, Treanor J, Baric RS "Cellular and Humoral Immunity following Snow Mountain Virus Challenge", J. Virol. 79 (5): 2900-2909, 2005.
[27] Leon J., “Chapter 9”. In Vajdy, Michael. Immunity Against Mucosal Pathogens. 2008.

[28] Asher I, Boner A, Chuchalin A, Custovic A, Dagli E, Haus M, Hemmo-Lotem M, Holgate S T, Holt P G, Høst A, "Prevention of allergy and asthma", Interim. report. Allergy, 55: 1069-1088, 2000.

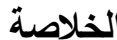

أن تحديد العوامل الفيروسية منل فيروس النورو النمط الأول (NVGI) والنمط الثاني (NVGII) والفيروس ألعجلي أمر بالغ الأهمية لوضع تدابير وقائية فعالة. هذه الدراسة تهدف إلى تحديد مدى انتشار الفيروسات المعوية الثائعة في الأطفال دون ه سنوات من العمر الذين يعانون

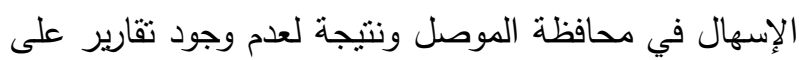

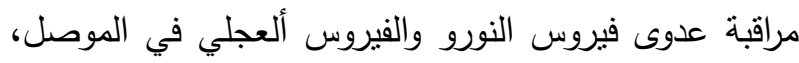

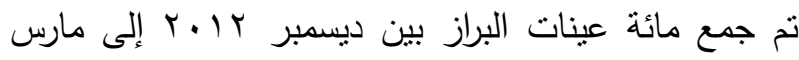

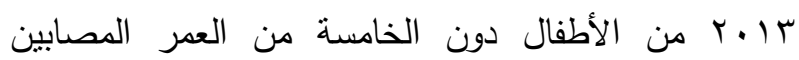
بالتهاب المعدة والأمعاء الحاد في مسنتفى السلام و ومختبر المدينة في الموصل والتحري عن الفيروس ألعجلي باستخدام اختبار تراص اللاتكس، والتحري عن فيروس النورو بنمطيه NVGI و NVGII بتقنية تفاعل البلمرة النسلسلي الآني ونم الكثف عن الفيروسات المعوية في r ع عينة من أصل . . 1.

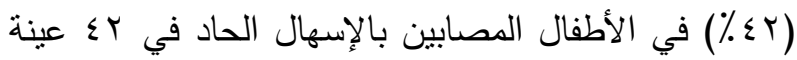

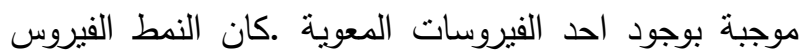
الأكثر شيوعا بينهم أذ تم تحديده في ؟ب الب حالة (؟.OV)

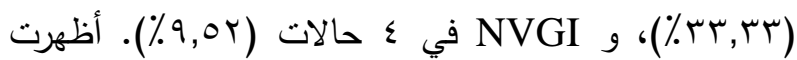
نتيجة العدوى انتشار عالي للفيروسات على حد سواء في الفئة العمرية أقل من / سنة مع ارتفاع معدل الإصابة في

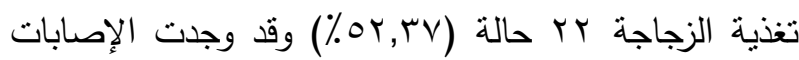

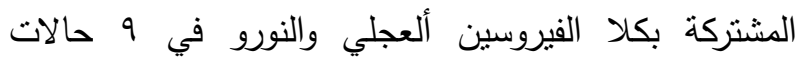

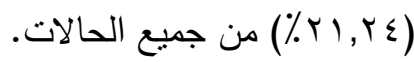

